УдК: [311.3:33] (477)

JEL Classification: C 15

\author{
Р. О. КУЛИНИЧ, \\ доктор економічних наук, професор, \\ завідувач кафедри математики, статистики \\ та інформачійних технологій, \\ Хиельницький університет управління та права \\ Ю. Є. ПРИДАННИКОВА, \\ аспірант Хиельничького університету \\ управління та права, \\ провідний економіст \\ Головного управління статистики Харківської області
}

\title{
Застосування методу статистичних рівнянь залежностей для оцінювання динаміки індексу регіонального людського розвитку Хмельницької області
}

На основі застосування методу статистичних рівнянь залежностей розроблено статистичний підхід до очінювання значень чинників, необхідних для досягнення запланованих або прогнозованих рівнів результативного показника, в тому числі при формуванні програм сочіально-економічного розвитку регіону. Розроблений підхід використано для очінювання динаміки індексу регіонального людського розвитку (ІРЛР) Хиельниџької області та показників, що його формують, за 2011-2015 роки. Розрахунки показали, що найбільщ значний вплив на величину ІРЛР Хмельничької області мають показники "Кількість мінімальни продуктових коииків, які можна придбати на середньодуиовий доход у регіоні, "Забезпеченість житлом у містах", "Сумарний коефічіент народжуваності".

Ключові слова: статистичні методи, кількісне очінювання взаємозв 'язків, метод статистичних рівнянь залежностей, програма сочіально-економічного розвитку, індекс регіонального людського розвитку Хмельничької області.

Постановка проблеми у загальному вигляді та її зв'язок із важливими науковими чи практичними завданнями. Перехід економіки на ринкові відносини зумовлює необхідність розрахунку економічних нормативів. Обгрунтування економічних нормативів за даними про зв'язок між різними чинниковими та результативними показниками діяльності досліджуваних регіонів (підприємств) дозволить відмовитися від традиційного способу планування показників соціально-економічного розвитку "від досягнутого рівня" на користь визначення прогнозних завдань на основі врахування впливу чинників на результативну ознаку (ВРП, обсяг зведеного та місцевих бюджетів, IPЛРіндекс регіонального людського розвитку).

В статистичній та економічній літературі багато уваги приділяється розрахункам і поясненню параметрів одночинникової та множинної регресії, обгрунтуванню критеріїв та умов їх прикладного використання. Інтерпретація параметрів багаточинникових рівнянь може призвести до помилкових висновків. Це відбувається тому, що у випадку одночинникової регресії ї̈ параметр пояснює вплив чинника, який вивчається, та всіх інших позв'язаних з ним чинників. Отже, чим більшу роль досліджуваний чинник займає у формуванні результативної ознаки, тим буде змістовнішою буде інтерпретація параметра регресії. Множинна регресія охоплює одночасну дію багатьох чинників, а теорія інтерпретації її параметрів вимагає елімінації (виклюучення) впливу всіх інших чинників, крім того чинника, який ми пояснюемо. Відомо, що в економічних явищах і процесах виклюучити вплив вусіх інших чинників неможливо, бо це означалотиме б зупинення їх розвитку.

Метод статистичних рівнянь залежностей дозволяс здійснити статистичний аналіз взасмозв'язків між соціально-економічнихми явищами та процессівами на основі різних форм (лінійних та нелінійних) та напрямків взаємозалежності: прямого, оберне-

w Р. О. Кулинич, Ю. Є. Приданникова, 2017 
ного та комбінаційного. Основними завданнями аналізу взаємозв'язку між соціальноекономічнихми явищами та процесівами, на основі методу статистичних рівнянь залежностей за вихідними даними динамічних та варіаційних рядів як нечисленних, так і численних сукупностей, $\epsilon$ наступнітакі [7]:

1) розв'язання прямої задачі: “Визначення рівня та розміру зміни результативної ознаки при зміні чинника (чинників) на одиницю чи будь-яку задану величину";

2) розв'язання оберненої задачі: “Визначення рівнів чинника (чинників) та розміру їх зміни при зміні результативної ознаки на одиницю чи будь-яку задану величину";

3) на основі розв'язання оберненої задачі визначення ступеня інтенсивності використання чинників для забезпечення формування середнього (запланованого, прогнозованого тощо) рівня результативної ознаки;

4) на основі множинної моделі взаємозв'язку. обчислення частки впливу чинників, включених до розрахунків, на результативну ознаку;

5) побудова функціональних теоретичних моделей розвитку соціально-економічних явищ та процесів;

6) кількіснае оцінкаювання розміру зміни рівнів чинників для забезпечення заданого (прогнозованого, нормативного або планового) рівня економічного явища, чи навпаки - рівнів результативного показника при заданих (відомих) значеннях чинників, і визначення при цьому необхідних затрат ресурсів подля кожномуого чинникуа у вартісному вираженні, тобто встановлення ресурсів підвищення економічної ефективності;

7) обчислення середнього темпу зміни економічного явища в результаті дії чинників (за даними варіаційних та динамічних рядів - для кожного періоду: року, кварталу, місяця) як на основі одночинникових, так і множинних моделей;

8) моделювання динаміки економічних явищ і процесів та обгрунтування прогнозних рівнів економічних явищ;

9) побудова графіків одночинникової та множинної залежності;

10) оцінкаювання інтенсивності використання чинників, що формують розвиток рівня економічного явища за кожний період (рік, квартал, місяць тощо) ряду динаміки.

Аналіз останніх досліджень і публікацій. Питанням кількісного статистичного оцінювання взаємозв'язків між економічними явищами та процесами присвячені праці А. Головача [1], I. Манцурова [2], Н. Парфенцевої [3], О. Осауленка [4] та інших вчених.

Статистичне дослідження взасмозв'язків між економічнихми явищами для обгрунтування управлінських рішень стосовно параметрів людського розвитку на регіональному рівні в контексті вивчення матеріального добробуту населення України потребує подальшоїї науково-методичноїі розробкики для прикладного застосування отриманих держаних результатів органами державної влади в цій галузі.

Формулювання мети статті (постановка завдання). Метою статті є аналіз прикладних аспектів застосування методу статистичних рівнянь залежностей для обгрунтування управлінських рішень стосовно параметрів людського розвитку на регіональному рівні на прикладі Хмельницької області.

Результати дослідження. Для адекватного оцінювання взаємозв'язків між економічними явищами і процесами потрібно застосовувати такі критерії вибору кращого статистичного рівняння залежності $[5 ; 10]$ :

$>$ порівняння графічного зображення емпіричної і теоретичної лінії значень результативного показника;

$>$ порівняння лінійної суми відхилень між емпіричними і теоретичними значеннями результативної ознаки за формулою: $\sum\left|Y-Y_{x}\right| \rightarrow \min$;

$>$ порівняння значень коефіцієнта стійкості зв'язку.

Основними критеріями вибору форми і виду рівняння залежності $є$ розрахунок лінійних відхилень між емпіричними і теоретичними лініями результативної ознаки 
та коефіцієнта стійкості зв'язку. Чим меншою є сума відхилень, тим краще рівняння залежності характеризуватиме розвиток економічного явища. Достовірну оцінку взаємозв'язку між економічними явищами можна отримати при значенні коефіцієнта стійкості зв'язку від 0,7 до $1,0[6]$.

Побудова економічних нормативів передбачає розв'язання таких основних задач кількісного оцінювання взаємозв'язків між економічними явищами:

1) встановлення зміни результативної ознаки при зміні чинника на одиницю чи будь-яку задану величину;

2) визначення частки впливу чинників на розвиток результативної ознаки;

3) визначення необхідної зміни рівнів чинників, що формують зміну величини результативної ознаки на одиницю чи іншу задану величину (обернена задача).

Розглянемо методичні положення застосування методу статистичних рівнянь залежностей для кількісного оцінювання взаємозв'язку між показниками, що використовуються для визначення індексу регіонального людського розвитку (IPЛР) Хмельницької області. Для розрахунків використаємо відносні величини інтенсивності 3 метою об'єктивного порівняння наявного стану за визначений період (рік) на прикладі таких показників:

$>$ результативна ознака-IРЛР Хмельницької області 2011-2015 роки, $y$;

$>$ чинникові ознаки:

1) сумарний коефіцієнт народжуваності, $x_{i}$;

2) забезпеченість житлом у містах (загальна площа у розрахунку на 1 особу), кв. м., $x_{2}$;

3) планова ємність амбулаторно-поліклінічних закладів (на 10 тис. населення), $x_{3}$;

4) кількість мінімальних продуктових кошиків, які можна придбати на середньодушовий доход у регіоні, $x_{\downarrow}$;

5) чистий показник охоплення дошкільними навчальними закладами дітей 3-5 років, $\%, x_{j}$;

6) охоплення загальною середньою освітою дітей шкільного віку (6-18 років), \%, $x_{6}$;

7) середній бал за результатами зовнішнього незалежного оцінювання (по всім предметам), $x_{\tau}$

Вихідні дані для аналізу взаємозв'язку між показниками IPЛР Хмельницької області розмістимо в табл. 1 .

Таблиия 1

Динаміка індексу регіонального людського розвитку та показників, що його формують у Хмельницькій області, за 2011-2015 pp.

\begin{tabular}{|c|c|c|c|c|c|c|c|c|}
\hline \multirow{2}{*}{ Роки } & \multicolumn{7}{|c|}{ Чинники } & Результативна \\
\cline { 2 - 8 } & $\boldsymbol{x}_{\mathbf{1}}$ & $\boldsymbol{x}_{\mathbf{2}}$ & $\boldsymbol{x}_{\boldsymbol{3}}$ & $\boldsymbol{x}_{\boldsymbol{q}}$ & $\boldsymbol{x}_{\mathbf{5}}$ & $\boldsymbol{x}_{6}$ & $\boldsymbol{x}_{\mathbf{7}}$ & ознака, $\boldsymbol{y}$ \\
\hline 2011 & 1,56 & 14,60 & $\mathbf{1 9 2 , 9 0}$ & 2,26 & 91,30 & 99,20 & 151,63 & 3,54 \\
\hline 2012 & 1,62 & 16,00 & 197,52 & 3,31 & 94,55 & 99,28 & 149,03 & 3,67 \\
\hline 2013 & 1,61 & 16,41 & 199,40 & 3,36 & 94,50 & 99,30 & 149,78 & 3,72 \\
\hline 2014 & 1,64 & 17,68 & 200,54 & 3,19 & 93,50 & 99,10 & 149,38 & 3,69 \\
\hline 2015 & 1,59 & 16,66 & 202,80 & 3,18 & 92,95 & 99,10 & 149,38 & 3,65 \\
\hline
\end{tabular}

Джерело: [11;12]

Для розрахунку параметрів одночинникового параболічного взаємозв'язку між кожним чинником та результативним показником - IPЛР Хмельницької області використаємо формулу методу статистичних рівнянь параболічної залежності при одночинниковому зв'язку [7]:

$$
y_{x}=y_{\text {min }}\left(1+b d_{1} \frac{\left(x_{x} \leq x_{0}\right) !\left(x_{2} 2 x_{0}\right)}{x_{0}}\right),
$$

де $y_{x}-$ теоретичне значення результативної ознаки, визначене за рівнянням залежності; $y_{\max }$ - фактичне мінімальне значення результативної ознаки; $b$-параметр рівняння одночинникової залежності; $x_{0}-$ значення чинникової ознаки, що відповідає мінімальному значенню результативного показника. 


\section{СТАТИСтикА}

Для оцінювання стійкості зв'язку обчислимо також коефіцієнт стійкості за формулою [9]:

$$
K=1-\frac{\sum\left|d_{y}-b d_{x}\right|}{\sum d_{y}},
$$

де $K$ - коефіцієнт стійкості зв'язку, визначений за методом статистичних рівнянь залежностей; $d-$ - значення коефіцієнта порівняння результативної ознаки; $b$-параметр рівняння одночинникової залежності; $d_{x}-$ значення коефіцієнта порівняння чинникової ознаки.

Параметри одночинникових рівнянь та коефіцієнтів стійкості зв'язку, обчислені з використанням сучасного комп'ютерного забезпечення за даними табл. 1, помістимо у табл. 2.

Таблиия 2

Значення параметрів рівнянь одночинникової залежності та коефіцієнтів стійкості зв'язку

\begin{tabular}{|c|c|c|c|c|}
\hline № & Чинник & Пара & метри рівнянь залежності & \begin{tabular}{|l} 
Стійкість \\
зв'язку
\end{tabular} \\
\hline 1 & $\begin{array}{l}\text { Сумарний коефіціснт } \\
\text { народжуваності, } x_{l}\end{array}$ & $y_{x}=3,54$ & $\left.1+1,0355 d_{1-\frac{\left(x_{i}: 1,56\right)}{1,56}}: \frac{\left(x_{x}, 21,56\right)}{1,56}-1\right)$ & 0,70 \\
\hline 2 & \begin{tabular}{|l|} 
Забезпеченість жит- \\
лом у містах (загальна \\
площа у розрахунку \\
на 1 особу), кв. м., $x$,
\end{tabular} & $y_{x}=3,54$ & 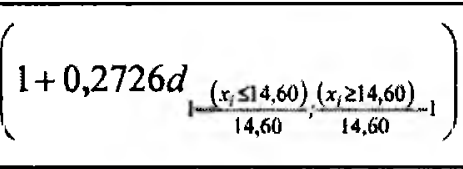 & 0,70 \\
\hline 3 & \begin{tabular}{|l|} 
Планова ємність \\
амбулаторно-полік- \\
лінічних закладів (на \\
10 тис. населення), $x_{z}$ \\
\end{tabular} & $y_{x}=3,54$ & $1+1,0497 d_{1-\frac{(x, 5192,90)}{192,90}} \frac{\left(x_{x}, 2192,90\right)}{192,90}-1$ & 0,70 \\
\hline$\overline{4}$ & \begin{tabular}{|l|} 
Кількість мінімальних \\
продуктових кошиків, \\
які можна придбати \\
на середньодушовий \\
доход у регіоні, $x$,
\end{tabular} & $y_{x}=3,54$ & $\left(1+0,0878 d_{1-\frac{\left(x_{i} \leq 2,26\right)}{2,26}} \frac{\left(x_{x}, 22,26\right)}{2,26}-1\right)$ & 0,85 \\
\hline 5 & \begin{tabular}{|l|} 
Чистий показник охо- \\
плення дошкільними \\
навчальними заклада- \\
ми дітей \\
$3-5$ років, $\%, x_{\tau}$ \\
\end{tabular} & $y_{x}=3,54$ & 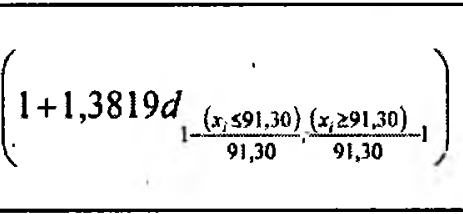 & 0,82 \\
\hline 6 & \begin{tabular}{|l|} 
Охоплення загальною \\
середньою освітою \\
дітей шкільного віку \\
$(6-18$ років), $\%, x$
\end{tabular} & $y_{x}=3,54$ & $\left(1+40,4349 d_{1-}-\frac{\left(x_{i} \leq 999,20\right)}{99,20} \frac{\left(x_{i} ; 299,20\right)}{99,20}-1\right.$ & 0,86 \\
\hline 7 & \begin{tabular}{|l|} 
Середній бал за \\
результатами зовніш- \\
нього незалежного \\
оцінювання (по всім \\
предметам), $x_{7}$
\end{tabular} & $y_{x}=3,54$ & $\left(1+40,4349 d_{1-\frac{\left(x_{1}, 599,20\right)}{99,20}} \frac{\left(x_{i} z 99,20\right)}{=99,20}-1\right.$ & 0,75 \\
\hline
\end{tabular}

Джерело: розраховано авторами за даними табл. $1 ;$ [8; 9]

Дані табл. 2 свідчать, що всі відібрані чинники можуть бути використані для проведення достовірних аналітичних розрахунків (значення коефіцієнта стійкості зв'язку дорівнюють або перевищують 0,7).) Між результативною ознакою (ІРЛР Хмельницької області) та обраними для подальших аналітичних розрахунків чинниками має місце параболічний зв'язок. 
Для розв'язання оберненої задачі', тобто визначення необхідної зміни рівнів чинникових ознак для забезпечення зростання IPЛР Хмельнииькой області в наступному (поточному) 2016 . до значення 4 (темп приросту відносно значення, досягнутого в 2015 р., становить 9,7\%), що відповідає першій десятці рейтингу регіонів України за IPЛР у 2015 р. [1 1; 12], визначимо розмір відхилень коефіцієнта порівняння заданого, прогнозованого або нормативного значення результативної ознаки $\left(y_{n}\right)$ з його попереднім рівнем, досягнутим у 2015 р. [10]:

$$
d_{y_{w}}=\frac{y_{n}}{y_{2015}}-1=\frac{4,00}{3,65}-1=0,097 \text {. }
$$

Розрахунок методом статистичних рівнянь залежностей нормативних значень чинників регіонального розвитку для забезпечення процесу їх вирівнювання, з орієнтацією на досягнення заданого річного темпу приросту результативного показника на рівні $9,7 \%\left(d_{y_{H}}\right)$, передбачає встановлення нормативних рівнів чинників за формулою при параболічній залежності [7]:

$$
x_{n}=\left(\frac{d_{y_{n}}}{b_{x}}+1\right) x_{2015}
$$

Наприклад, для чинника “Сумарний коефіцієнт народжуваності, $x_{l}$ ” розрахункове значення складе:

$$
x_{n}=\left(\frac{0,097}{1,0355}+1\right) 1,59=1,74 .
$$

Проведені розрахунки нормативних значень чинників формування IРЛР Хмельницької області розмістимо в табл. 3.

\begin{tabular}{|c|c|c|c|}
\hline \multirow[t]{2}{*}{ Показник } & \multirow[t]{2}{*}{$\begin{array}{c}\text { Розрахункове } \\
\text { нормативне } \\
\text { значення } \\
\text { чинника }\end{array}$} & \multicolumn{2}{|c|}{\begin{tabular}{|c} 
Необхідна зміна чин- \\
ника для досягнення \\
нормативної зміни ІРЛР \\
Хмельницької області \\
порівняно з попереднім \\
2015 р. \\
\end{tabular}} \\
\hline & & $\begin{array}{c}\text { рівень } \\
\text { приросту }\end{array}$ & $\begin{array}{c}\text { темп } \\
\text { приросту, \% }\end{array}$ \\
\hline Сумарний коефіцієнт народжуваності, $x$, & 1,74 & 0,15 & 9,3 \\
\hline $\begin{array}{l}\text { Забезпеченість житлом у містах (загальна } \\
\text { плоша у розрахунку на } 1 \text { особу), кв. м., } x \text {, }\end{array}$ & 22,56 & $.5,90$ & 35,4 \\
\hline $\begin{array}{l}\text { Планова ємність амбулаторно-поліклініч- } \\
\text { них закладів (на } 10 \text { тис. населення), } x_{2} \\
\end{array}$ & 221,45 & 18,65 & 9,2 \\
\hline $\begin{array}{l}\text { Кількість мінімальних продуктових коши- } \\
\text { ків, які можна придббати на середньодушо- } \\
\text { вий доход у регіоні, } x \text {, }\end{array}$ & 6,67 & 3,49 & 109,9 \\
\hline $\begin{array}{l}\text { Чистий показник охоплення дошкільними } \\
\text { навчальними закладами дітей 3-5 років, } \\
\%, x_{\varepsilon}\end{array}$ & 99,44 & 6,49 & 7,0 \\
\hline $\begin{array}{l}\text { Охоплення загальною середньою освітою } \\
\text { дітей шкільного віку (6-18 років), \%, } x_{\star}\end{array}$ & 99,34 & 0,24 & 0,2 \\
\hline $\begin{array}{l}\text { Середній бал за результатами зовнішнього } \\
\text { незалежного оцінювання (по всіх предме- } \\
\text { тах), } x_{7}\end{array}$ & 154,84 & 5,46 & 3,7 \\
\hline
\end{tabular}

Розрахункові нормативні значення чинників, що формують індекс регіонального людського розвитку Хмельницької області у 2016 р.

Джерело: розраховано авторами

${ }^{1}$ Методом регресійного аналізу ця задача не розв'язуеться. 


\section{СтатистикА}

Пї дані свідчать про необхідність залучення значних ресурсів для досягнення таких значень основних показників розвитку, які б забезпечили заданий темп зростання IPЛP Хмельницької області в $9,7 \%\left(d_{y_{H}}\right)$.

Встановлено, що на першому місці у рейтингу темпів зростання показників в Динаміці (\% порівняно з відповідними максимальними значеннями показників 2015 р.) серед кола досліджуваних показників, найбільше ресурсів для зростання потребує чинник: "Кількість мінімальних продуктових кошиків, які можна придбати на середньодушовий доход в регіоні" вдвічі до значення 6,67. На другому місці показник "Забезпеченість житлом у містах (загальна площа у розрахунку на 1 особу), кв. м" зі значенням відносної величини зростання на $35,4 \%$.

Визначимо також методом статистичних рівнянь залежностей частку впливу чинників, включених до розрахунків, на IРЛР Хмельницької області. Для розв'язання такої задачі застосуємо множинне рівняння параболічної залежності, яке визначимо за вихідними даними табл. 1. Враховуючи те, що між ІРЛР Хмельницької області та основними показниками його формування, прийнятими до розрахунків, існує параболічний взасмозв'язок, для розрахунків застосуємо рівняння багаточинникової параболічної залежності, параметри якого обчислюють за формулою²:

$$
y_{x=}=y_{\min }\left[1+B\left(d_{1-\frac{\left(x_{i j} x_{0}\right)}{x_{0}} ; \frac{\left(x_{0}, x_{0}\right)}{x_{0}}-1}+d_{\left.1-\frac{\left(z_{1}, z_{0}\right)}{z_{0}}\right)\left(\frac{\left(z_{i}, z_{0}\right)}{z_{0}}-1\right)}\right)\right] \text {, }
$$

де $y_{x z}$ - теоретичне значення результативного показника; $y_{\min }-$ мінімальне значення результативної ознаки; $B$ - сукупний параметр багаточинникової залежності; $d_{i}-$ символ відхилень коефіцієнтів порівняння чинникових ознак; $\mathrm{x}_{i}-$ значення чинникової ознаки, включеної до розрахунків; $x_{t}$ - значення чинникової ознаки, що відповідає мінімальному значенню результативної ознаки.

Рівняння багаточинникової прямої параболічної залежності має такий вигляд:

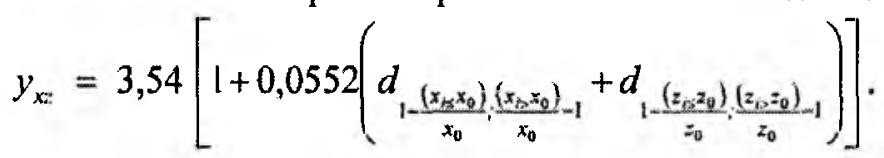

Проведений аналіз дає підстави стверджувати, що зміна сукупного розміру відхилень коефіцієнтів порівняння чинникових ознак $x_{i}=1, n$ на одиницю зумовлює зміну розміру відхилень теоретичних значень результативної ознаки $y$ в 0,0552 раза (див. рис. 1).

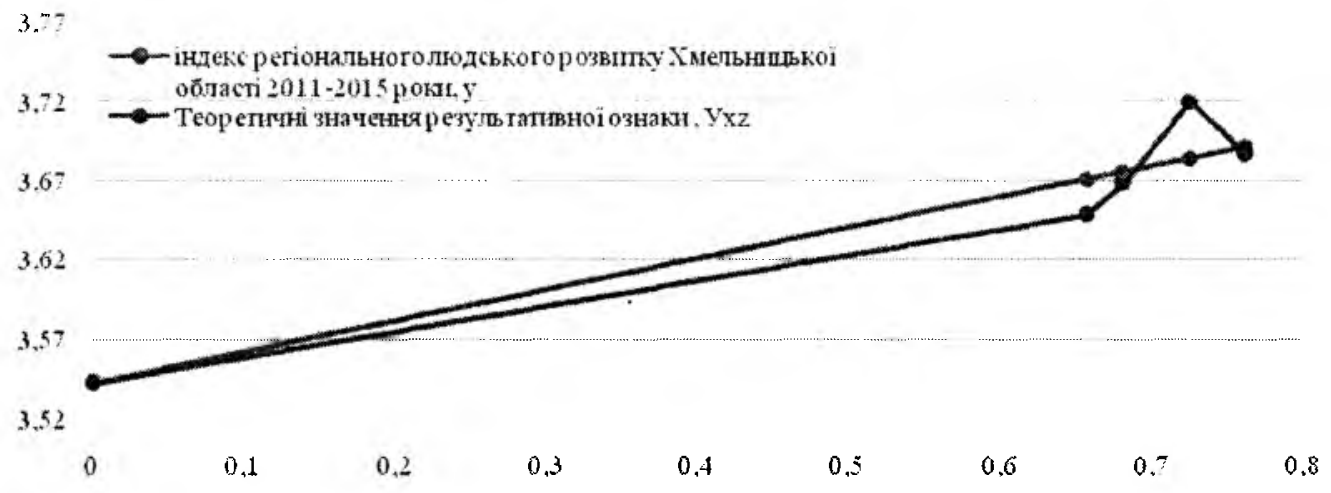

Рис. 1. Залежність індексу регіонального людського розвитку Хмельницької області від основних показників його формування 3a 2011-2015 pp.

Джерело: розраховано і побудовано авторами

\footnotetext{
${ }^{2}$ Рівняння багаточинникової лінійної прямої залежності та розрахунок його параметрів, а також значення, наведене в табл. 3 і на рис. 1 та 2, встановлено на основі використання комп'ютерної програми “Метод статистичних рівнянь залежностей”.
} 
ЗАСТОСУВАННЯ МЕТОДУ СТАТИСТИЧНИХ РІВНЯНЬ ЗАЛЕЖНОСТЕЙ ДЛЯ ОЦІНЮВАННЯ ДИНАМІКИ ІНДЕКСУ РЕГЮОНАЛЬНОГО ЛЮДСЬКОГО РОЗВИТКУ ХМЕЛЬНИЦЬКОЙ ОБЛАСТІ

Встановимо частку впливу включених до розрахунків показників на формування IPЛP Хмельницької області за досліджуваний період (див. табл. 4).

Таблищя 4

Рейтинг чинників за їх часткою впливу на індекс регіонального людсъкого розвитку Хмельницької області за 2011-2015 pp.

\begin{tabular}{|c|c|c|c|}
\hline Уиньик & $\begin{array}{c}\text { Сума } \\
\text { коефіціснтів } \\
\text { порівняння } \\
\text { досліджуваних } \\
\text { чинвиків } \\
\sum d_{x_{i}}\end{array}$ & $\begin{array}{c}\text { पастка } \\
\text { вплкву } \\
\text { кожного } \\
\text { чинника на } \\
\text { результативну } \\
\text { ознаку, \% } \\
\Delta_{x}=\frac{\sum d_{x_{f}}}{\sum d_{i_{x_{i}}}}\end{array}$ & $\begin{array}{l}\text { Рейтинг } \\
\text { впливу } \\
\text { чняника }\end{array}$ \\
\hline $\begin{array}{l}\text { Сумарний коефіціент } \\
\text { народжуваності, } x_{I}\end{array}$ & 0,1506 & 5,33 & 3 \\
\hline $\begin{array}{l}\text { Забезпеченість житлом у містах } \\
\text { (загапьна плома у розрахунку на } \\
1 \text { особу), кв. м., } x_{2}\end{array}$ & 0,5722 & 20,27 & 2 \\
\hline $\begin{array}{l}\text { Планова ємність амбулаторно- } \\
\text { поліклінічних закладів (на } 10 \text { тис. } \\
\text { населенкя), } x_{3}\end{array}$ & 0,1486 & 5,26 & 4 \\
\hline $\begin{array}{l}\text { Кількість мінімальних продуктових } \\
\text { кошиків, які можна придбати на } \\
\text { середиьодушовий доход у регіоні, } x_{4}\end{array}$ & 1,7762 & 62,91 & l \\
\hline $\begin{array}{l}\text { Чистий показник охопления } \\
\text { дошкільними навчальними } \\
\text { закладами дітей } 3-5 \text { років, } \%, x_{9}\end{array}$ & 0,1129 & 4,00 & 5 \\
\hline $\begin{array}{l}\text { Oxоплення загальною середньою } \\
\text { освітою дітей шкільного віку } \\
\text { (6-18 років), } \%, x_{6}\end{array}$ & 0,0039 & 0,14 & 7 \\
\hline $\begin{array}{l}\text { Середній бал за результатами } \\
\text { зовиішнього незалежного } \\
\text { оціновання (по всіх предметах), } x_{7}\end{array}$ & 0,0590 & 2,09 & 6 \\
\hline Рaзom & 2,8234 & 100,00 & - \\
\hline
\end{tabular}

Джерело: розраховано авторами

Дані табл. 4 свідчать, що найбільш значний вплив на ІРЛР Хмельницької області мають чинники "Кількість мінімальних продуктових кошиків які можна придбати на середньодуиовий доход у регіоні, $x_{\text {, " }}(62,91 \%)$, "Забезпеченість жситлом у містах (загальна плоища у розрахунку на 1 особу), кв. м., $x_{2}$ " (20,27\%), на третьому місці чинник "Сумарний коефіиієнт народжуваності, $x_{1}$ " (5,33\%).

Такі чинники як "Планова ємність амбулаторно-поліклінічних закладів (на 10 тис. населення), $x_{3}$ ", "Охоплення загальною середньою освітою дітей икільного віку (6-18 років), \%, $x_{6}$ " мають ступінь впливу на обсяг надходжень до місцевих бюджетів України від 5,26 до 0,14\%.

Висновки та перспективи подальших розвідок. Прагнення до досягнення кращих результатів та вирівнювання показників регіонального розвитку з відповідною орієнтацією на оптимальні значення чинників, що його формують (максимальні для показників-стимуляторів і мінімальні для показників-дестимуляторів) є основою при обгрунтуванні параметрів людського розвитку на регіональному рівні. 
Розв'язання такого важливого завдання як визначення оптимальних рівнів чинників та результативних показників людського розвитку грунтується на розв'язанні оберненої задачі як однієї з функціональних можливостей методу статистичних рівнянь залежностей. Застосування цього методу дозволяє розв' язувати як прямі, так і обернені задачі, що постійно зустрічаються на практиці при встановленні значень чинникових ознак, для формування рівня розвитку результативного показника, виявлення зв'язків, закономірностей, тенденцій розвитку, моделювання і прийняття управлінських рішень та при обгрунтуванні програм регіонального розвитку.

Пропонована методика застосування методу статистичних рівнянь залежностей для моделювання динаміки чинників та результативних показників при обгрунтуванні параметрів людського розвитку на регіональному рівні може бути використана у всіх видах економічної діяльності. Тоді буде необхідно уточнити перелік показників, що характеризують соціально-економічний розвиток та специфіку господарсько-фінансової діяльності цих суб'сктів.

Розглянуті прикладні аспекти застосування методу статистичних рівнянь залежностей як статистичного способу кількісного оцінювання взаємозв'язків для обгрунтування параметрів людського розвитку на регіональному рівні бажано доповнити також відповідними розрахунками на основі вихідних даних усіх показників, що формують людський розвиток.

\section{Список використаних джерел}

1. Головач А. В., Захожай В. Б., Головач Н. А. Статистичне забезпечення управління економікою: прикладна статистика: навч. посіб. К.: КНЕУ, 2005. 333 с.

2. Манцуров І. Г. Статистика економічного зростання та конкурентоспроможності країни: моногр. К.: КНЕУ, 2006. 392 с.

3. Статистика ринків: підруч. для вищ. навч. закл. / ДАСОА Держкомстату України; за наук. ред. Н. О. Парфенцевої. К.: "Інформ.-аналіт. агентство", 2007. 863 с.

4. Осауленко О.Г. Національна статистична система: стратегічне планування, методологія та організація: моногр. К.: “Інформ.-аналіт. агентство”, 2008. 415 с.

5. Кулинич Е. И. Эконометрия. 3-е изд., стереотип. М.: Финансы и статистика, 2001. $304 \mathrm{c}$.

6. Кулинич О. І. Економетрія: навч. посіб. Хмельницький: Поділля, 2003. 215 с.

7. Кулинич О. І., Кулинич Р. О. Теорія статистики: підруч. 7-е вид., перероб. і доп. К.: Знання, 2015.239 с.

8. Кулинич Р. О. Програмне забезпечення статистичних методів [Електронний pecypc] / Персональний сайт P. O. Кулинича. URL: http://www.kulynych.in.ua/ software-statistical-methods

9. Кулинич Р. О. Статистична оцінка чинників соціально-економічного розвитку: моногр. К.: Знання, 2007. 311 с.

10. Кулинич Р. О. Статистичні методи аналізу взаємозв'язку показників соціальноекономічного розвитку: моногр. К.: Формат, 2008. 288 с.

11. Індекс регіонального людського розвитку [Електронний ресурс] / Інститут демографії та соціальних досліджень імені М. В. Птухи НАН України. URL: http:// www.idss.org.ua/ukr index/irlr 2014.html

12. Регіональний людський розвиток за 2015 р.: бюлетень. Державна служба статистики України. К., 2016.57 с. 
доктор экономических наук, профессор, заведуючий кафедрой математики, статистики и информачионных технологий Хиельницкий университет управленияи права Ю. Е. ПРИДАННИКОВА,

аспирант Хиельничкого университета управления и права, ведучий экономист

Главного управления статистики Харьковской области

\section{Применение метода статистических уравнений зависимостей для оценивания динамики индекса регионального человеческого развития Хмельницкой области}

На основе применения метода статистических уравнений зависимостей разработан статистический подход кочениванию значений факторов, необходииых для достижения запланированных либо прогнозируемых уровней результативного показателя, в том числе при формировании программ сочиально-экономического развития региона. Разработанный подход использован для оченивания динамики индекса регионального человеческого развития (ИРЧР) Хмельниикой области и показателей, которые его формируют, за 2011-2015 годы. Расчеты показали, что наиболее значительное влияние на величину ИРЧР имеют показатели «Количество минимальных продовольственных корзин, которые можно приобрести на среднедушевой доход в регионе», "Обеспеченность жилье в городах», "Сумиарный коэффиұиент рождаемости».

Ключевые слова: статистические методы, количественное оченивание взаимосвязей, метод статистичесих уравнениий зависимостей, программа сочиальноэкономического развития, индекс регионатьного человеческого развития Хиельницкой области.

R. O. KULYNYCH,

Dsc (Economics), Professor, Head of Department for Mathematics, Statistics and Information Technologies, Khmelnytsk University of Management and Law . YU. E. PRYDANNYKOVA, аспирант Хиельниикого университета управления и права, ведуиий экономист

Главного управления статистики Харьковской области

\section{Application of the Method of Statistical Equations of Dependences to Assess the Dynamics of Regional Human Development Indx for Khmelniytsk Region}

A statistical approach to assessment of the factor values required to have necessary (planned, predicted) levels of a resulting indicator achieved, including for purposes of regional socio-economic programs, is developed, by applying the method of statistical equations of dependences.

The main problems that can be solved by use of the method of statistical equations of dependences are: direct and inverse problem; computing the factors' contributions in the resulting indicator; constructing graphs of multiple relation and computing the shares of influence (the weights of selected factors); analysis of functional and correlation dependences, etc. 
The developed approach is used to assess the dynamics of Regional Human Development Index (RHD) for Khmelniytsk region (Ukraine) and its constituent factors, in 2011-2015. The computations show that the factors with the largest contribution in RDI of Khmelniytsk region are as follows: "number of minimal food baskets that can be purchased for average per capita income in the region" (62.91\%), "housing in cities (square area per person)" $(20.27 \%)$, and "total birth rate" $(5.33 \%)$. The contributions of factors like "planned capacity of ambulatories and policlinics per 10 thousand population" or "coverage of children in school age by secondary education" range from 5.26 to $0.14 \%$.

It is concluded that the proposed approach to the application of the method of statistical equations of dependences for modeling of factor and resulting indicators contributing to human development parameters at regional level can be used for assessments at sectoral level, with modifying the nomenclature of indicators measuring the socio-economic development and the financial and economic performance of business entities in an economic sector.

Keywords: statistical methods, quantitative assessment of relations; method of statistical equations of dependences, program of socio-economic development, Regional Human Development Indx for Khmelniytsk region.

\section{Посилання на статтю:}

Кулинич Р. О., Приданникова Ю. Є. Застосування методу статистичних рівнянь залежностей для оцінювання динаміки індексу регіонального людського розвитку Хмельницької області: зб. наук. пр.. 2017. №4. С. 13-22. 